Vol 10, Issue 6, 2017

\title{
SURVEY, ISOLATION, BIOCHEMICAL CHARACTERIZATION, AND IDENTIFICATION OF HELICOBACTER PYLORI FROM GASTRIC PATIENT BIOPSY
}

\author{
THIRUNAVUKKARASU $\mathbf{P}^{1,3 *}$, ASHA $\mathbf{S}^{2}$, ROHITH KUMARREDDY ${ }^{1}$, RAMANATHAN $\mathbf{T}^{3}$, SUDHAKAR $\mathbf{N}^{1}$ \\ ${ }^{1}$ Department of Biotechnology, Dr. M.G.R. Educational and Research Institute University, Chennai - 600 095, Tamil Nadu, India. \\ ${ }^{2}$ Department of Biochemistry, DKM College for Women, Vellore, Tamil Nadu, India. ${ }^{3}$ Centre of Advanced Study in Marine Biology, \\ Faculty of Marine Sciences, Annamalai University, Cuddalore - 608 502, Tamil Nadu, India. Email: ppthirunacas@gmail.com
}

Received: 24 March 2017, Revised and Accepted: 09 May 2017

ABSTRACT

Objective: This study was to isolate and identify the Helicobacter pylori from the biopsy samples of the gastric patient.

Methods: Gastric biopsies were collected from the antral region of the gastric patient. Out of 96 patients, 59 males and 37 females in the age group between 11 and 70 years old were selected. A serial dilution of the sample was made. The bacterial colonies were examined on the basis of Gram staining, colony morphology, and biochemical reactions such as catalase, urease, oxidase, nitrate reduction, glycine utilization, growth (different media, different temperature, and salt tolerance), and antibiotic sensitivity.

Result: From the findings, it was found that 75\% (65\% of male and 35\% of female) have $H$. pylori infection remaining $25 \%$ were not infected. The rate of infection was found to be more in age group 55-65 and less in age group below 25 . Among $75 \%$ of $H$. pylori infected patients, $72 \%$ are affected with ulcer, $19 \%$ with gastric cancer, and $8.3 \%$ found to be non-gastric inflammated. Gram staining result declared that the isolated bacteria from the biopsy sample observed to be Gram-negative, spiral shaped rod. Biochemical reports produced positive indication to all the tests.

Conclusion: Based on the morphological, staining and biochemical test result, it was confirmed that the isolated bacteria was found to be $H$. pylori. Gastric cancer is the fourth most common cancer and the second leading cause of cancer-related to death worldwide. In 1994, the international agency for research on cancer classified H. pylori as a Class I (definite) carcinogen, as H. pylori infection is considered as an important trigger in the process of carcinogenesis of both types of distal gastric cancer.

Keywords: Helicobacter pylori, Gastric patient, Biopsy, Gram staining, Biochemical assay.

(C) 2017 The Authors. Published by Innovare Academic Sciences Pvt Ltd. This is an open accessarticle under the CC BYlicense (http://creativecommons. org/licenses/by/4. 0/) DOI: http://dx.doi.org/10.22159/ajpcr.2017.v10i6.18670

\section{INTRODUCTION}

The Helicobacter genus belongs to a group of microaerophilic, nonsporulating, Gram-negative, spiral-shaped bacterium [1], which colonizes the mucous layer in the epithelial surface of the gastrointestinal tract and lymphoid tissue of human beings [2]. Earlier, some Helicobacter species such as Helicobacter aurati, Helicobacter bilis, and Helicobacter muridarum were isolated from both gastric and entero hepatic sites [3]. In world's population, approximately, $50 \%$ of colonized Helicobacter pylori varied by prevalence, age, country, ethnic background, and socioeconomic conditions [4]. The prevalence in developing countries can be as high as $80-90 \%$, whereas it is lower in industrialized countries, ranging between $10 \%$ and $50 \%$ [5].

Initially Warren and Marshall [6], first isolated H. pylori bacterium from gastric biopsies patients with active chronic gastritis, duodenal ulcer or gastric ulcer, and gastric cancer [7]. They were later awarded the Nobel Prize in 2005 for their discovery of $H$. pylori and its role in gastritis and peptic ulcer disease. Several researchers confirmed that $H$. pylori eradication cured peptic ulcer [8-10] gastroduodenal disease [11,12]. Hence, this study was designed to isolate and identify the $H$. pylori from biopsy samples of the gastric patient.

\section{METHODS}

Preliminary standardization experiments were conducted and only those which gave reproducible results were adopted.

\section{Reagents}

Biopsy samples from gastric patients, Columbia agar, Brucella broth, heat infusion agar, serum supplemented plate agar nutrient agar, Gram's iodine, crystal violet, safranin and ethyl alcohol.

\section{Isolation of bacterium}

A total of 96 patients with a male-to-female ratio (59 males and 37 females), ranging from 11 to 70 years old with dyspeptic symptoms were studied from the M/s Maruthi Gastro Care Hospital, Cuddalore, Tamil Nadu, India. Gastric biopsies from the antral region were obtained through esophagogastroduodenoscopy from each patient. Biopsy samples were collected in pre-sterilized vials and stored them in an ice pot immediately until transfer to ultra-freezer at $-20--40^{\circ} \mathrm{C}$. Number or identification codes were given based on the samples collected. Each biopsy sample was ground in $1 \mathrm{~mL}$ of biological saline water using presterilized tissue grinder.

About $1 \mathrm{~mL}$ of sample was serially diluted with sterilized distilled saline up to $10^{-1}-10^{-10}$ and $100 \mu \mathrm{L}$ of each dilution was added to $20 \mathrm{~mL}$ of Columbia agar medium in $90 \mathrm{~mm}$ diameter sterile Petri dishes, then plates were incubated at $37^{\circ} \mathrm{C}$ for 10 days under the microaerophilic conditions (5\% 0,15\% $\mathrm{CO}_{2}$, and $80 \% \mathrm{~N}$ ) with an anaerobic jar system using Anaerocult C (Merck, Germany) $[3,13]$. A high degree of humidity during incubation was obtained by placing a wet paper towel in anaerobe jars. Plates were routinely observed for bacterial growth and to check contamination; a suggestive growth of a Helicobacter spp. was identified from $3^{\text {rd }}$ day, either as small (1 $\mathrm{mm}$ or less in diameter), clear, dome-shaped colonies or as a fine, translucent lawn [2]. Growing colonies were examined for $H$. pylori on the basis of colony morphology and positive biochemical reactions for catalase, urease, and oxidase (although many entero hepatic species are urease negative) and negative Gram-strain $[14,15]$. The growth of $H$. pylori after 3 days of incubation was confirmed using Bergey's Manual of Systematic Bacteriology [16], then it was subcultured on a selective medium and stored it below $-20^{\circ} \mathrm{C}$ until further use. 


\section{Colony and cell morphology}

Exponentially overnight grown cultures in Brucella broth (Vincent, 1970) were spread on Columbia agar plates and incubated at $37^{\circ} \mathrm{C}$ for $72 \mathrm{hrs}$. After $72 \mathrm{hrs}$, the color and morphology of the colonies were noted. Cell motility and shape of single colony was observed under light microscopy (Nikon, Japan). The bacterial species isolated from gastric patient biopsy samples were identified based on the Bergey's Manual of Systematic Bacteriology [16]

\section{Motility}

A loop full of culture was transferred to Brucella liquid medium and incubated on a rotary shaker operating at $200 \mathrm{rpm}$ at $37^{\circ} \mathrm{C}$. After $48 \mathrm{hrs}$ of incubation $100 \mu \mathrm{L}$ was tested for motility on cavity slide.

\section{Biochemical identification}

Urea hydrolysis [17]

The hydrolysis of urea was detected by streaking the culture on Christensen agar medium containing peptone besides urea and a small amount of glucose, with phenol red as an indicator and incubated for 2 days.

\section{Sterilized by filtration}

After sterilization of Part-A in flasks (100 mL/flask), $5 \mathrm{~mL}$ of Part-B solution added and the medium was used to prepare plates.

\section{Catalase production [18]}

The catalase test was performed directly on colonies growing on Columbia agar. Hydrogen peroxide $\left(\mathrm{H}_{2} \mathrm{O}_{2}\right)$ solution $(3 \%)$ was used to flood colonies.

\section{Test for oxidase [19]}

This was performed directly on colonies growing on Columbia agar. A 1\% aqueous tetramethyl-p-phenylene diamine-dihydrochloride (TMPPD regent) impregnated paper on which a loopful of young culture was streaked.

\section{Nitrate reduction [20]}

A loop full of exponentially grown culture was inoculated into nitrate broth and incubated at room temperature for 2-3 days. After visible growth, $1 \mathrm{~mL}$ of the nitrate broth was transferred to a clean test tube, a 2-3 drop of sulfanilic acid solution and 2-3 drop of $\alpha$-naphthylamine was added and allowed to stand for 5 minutes.

\section{Glycine utilization}

This test was performed with Columbia agar amented with $1 \%$ glycine. A loopful of young culture was streaked and incubated.

\section{Growth on different media}

A loop full of culture was transferred from purified slants and streaked on plates containing, Columbia agar, Brucella agar, blood agar, brain heart infusion agar, serum supplemented plate, and nutrient agar. These plates were incubated at $37^{\circ} \mathrm{C}$ for $72 \mathrm{hrs}$

\section{Optimum temperature for growth [18]}

The optimum temperature was determined in nutrient broth with a loopful of the bacterium as the inoculum at different temperature in increments $\left(25,30,35,40\right.$, and $\left.45^{\circ} \mathrm{C}\right)$.

\section{Salt tolerance [18]}

Salt tolerance was determined in Brucella broth with sodium chloride added at different concentrations $0.5,0.75,1.0,1.25$, and $1.5 \%(\mathrm{w} / \mathrm{v})$.

\section{Antibiotic resistance/sensitivity}

Since resistance to certain broad-spectrum antibiotics is a common feature of most of the H. pylori, antibiotic resistance of $H$. pylori was checked with the different group of antibiotics such as nalidixic acid, trimethoprim, vancomycin, penicillin, and tetramycine cephalothin. Then, minimum inhibitory concentration (MIC) was recorded.

\section{RESULTS}

During the period of isolation of bacteria from (March 2011) patients attended the endoscopy unit at M/s Maruthi gastro care Hospital, Cuddalore, Tamil Nadu, India. Complaining of suggestive symptoms of peptic ulcer disease such as upper abdominal pain, acidity, nausea, and vomiting were reported from these patients through the endoscopic process

The sample was collected in sterilized tube and immediately transferred to ice box within $2 \mathrm{hrs}$ and brought to the laboratory. The samples were ground with the help of sterile tissue grinder and $1 \mathrm{~mL}$ of biological saline was added. The isolated single colony through serial dilution method will be carried out. $10^{-7}$ was isolated better colonies. Further this microbe was confirmed based on morphological and microscope analysis. A total of 96 patient were checked as positive to endoscopic diagnosis during the study period. Out of 96 patients, 63 males and 33 females were aged 11-78 (Table 1). It was also found that a higher and lower level of $H$. pylori infection was observed in 55-65 age and below 25 age, respectively.

H. pylori infection was determined in 62 patients and non $H$. pylori infection in 34 patients. $H$. pylori infection in male patients was 43 and remaining 20 patients was non $H$. pylori infection in the same way, out of 33 female patients 22 have an $H$. pylori infection remaining 11 noninfections (Table 2)

In the present finding 65.5 and $33 \%$ of male and female patients were affected from gastric inflammation, respectively. $72 \%$ of patients affected with ulcer, $19 \%$ of patient affected with gastric cancer and $8.3 \%$ of patients found noninflammated. Higher cancer patients observed from the age between 35 and 45 age was 11.5\% (Table 3).

\section{Morphological observation}

The cells were straight, non-spore forming, motile, helical or curved, rounded ends and spiral periodicity, translucent colonies 1-2 mm in diameter, grows microaerophilically (Fig. 1). Gram's differential staining declared that the isolated bacterium was Gram-negative and spiral-shaped rods (Fig. 2).

Table 1: Distribution of patients with $H$. pylori and non-H. pylori ulcer by age group

\begin{tabular}{llll}
\hline Age (in years) & $\begin{array}{l}\text { Number of } \\
\text { patients } \\
\text { tested }\end{array}$ & H.pylori ulcer & $\begin{array}{l}\text { Non } \boldsymbol{H} \text {. pylori } \\
\text { ulcer }\end{array}$ \\
\cline { 3 - 4 } & & $\begin{array}{l}\text { Number of } \\
\text { patients } \\
\text { infected (\%) }\end{array}$ & $\begin{array}{l}\text { Number } \\
\text { of patient } \\
\text { infected (\%) }\end{array}$ \\
\hline Below 15 & 3 & $1(33)$ & $2(66)$ \\
$15-25$ & 13 & $8(61.5)$ & $5(38.4)$ \\
$25-35$ & 19 & $13(68.4)$ & $6(31.5)$ \\
$35-45$ & 26 & $17(65.3)$ & $9(34.6)$ \\
$45-55$ & 19 & $11(57.8)$ & $8(42.1)$ \\
$55-65$ & 16 & $12(75)$ & $4(25)$ \\
Total & 96 & $62(64.5)$ & $34(35.4)$ \\
\hline
\end{tabular}

H. pylori: Helicobacter pylori

Table 2: Distribution of patients with H. pylori and non-H. pylori ulcer by sex group

\begin{tabular}{llll}
\hline Sex & $\begin{array}{l}\text { Number } \\
\text { of patient }\end{array}$ & H. pylori ulcer & Non $\boldsymbol{H}$. pylori ulcer \\
\hline Male & 63 & $43-68.2$ & $20-31.7$ \\
Female & 33 & $22-66.6$ & $11-33.3$ \\
\hline
\end{tabular}

H. pylori: Helicobacter pylor 
Table 3: Determination of patient gastric ulcer, gastric cancer and non-gastric inflammation

\begin{tabular}{|c|c|c|c|c|c|c|}
\hline \multirow[t]{3}{*}{ Age (in years) } & \multirow[t]{3}{*}{ Number of patients } & \multicolumn{5}{|c|}{ Number of patients (\%) } \\
\hline & & \multicolumn{2}{|l|}{ Sex } & \multirow[t]{2}{*}{ Ulcer } & \multirow[t]{2}{*}{ Cancer } & \multirow[t]{2}{*}{ Non gastric inflammations } \\
\hline & & Male & Female & & & \\
\hline Below 25 & 16 & $10(62.5)$ & $6(37.5)$ & $4(25)$ & $1(6.2)$ & $11(68.7)$ \\
\hline $25-35$ & 19 & $12(63.1)$ & $7(36.8)$ & $15(78.9)$ & $3(15.7)$ & $1(5.2)$ \\
\hline $35-45$ & 26 & $17(65.3)$ & $9(34.6)$ & $18(69.2)$ & $5(19.2)$ & $3(11.5)$ \\
\hline $45-55$ & 19 & $14(73.6)$ & $5(26.3)$ & $12(63.1)$ & $6(31.5)$ & $1(5.2)$ \\
\hline Total & 96 & $63(65.6)$ & $33(34.3)$ & $70(72.9)$ & $19(19.7)$ & $8(8.3)$ \\
\hline
\end{tabular}

\section{Biochemical assay}

Urease test

The hydrolysis of urea was detected by streaking the culture on Christensen agar medium containing peptone besides urea and a small amount of glucose, with phenol red as an indicator and incubated $2 \mathrm{~d}$. Formation of pink color indicated that urea hydrolysis and the $\mathrm{pH}$ changes were due to the formation of ammonia (Table 4 and Fig. 3).

\section{Catalase test}

The catalase test was performed directly on colonies growing on nutrient agar. $\mathrm{H}_{2} \mathrm{O}_{2}$ solution (3\%) was used to flood colonies. A brisk effervescence indicated a positive test for catalase production (Table 4 and Fig. 4).

\section{Oxidase}

This was performed directly on colonies growing on Columbia agar. A $1 \%$ aqueous $N, N, N^{\prime}, N^{\prime}$-TMPPD regent impregnated paper on which a loopful of young culture was streaked. Bacterial culture turned purple (bluish black) color within $1 \mathrm{~min}$ indicated oxidase presence (Table 4 and Fig. 5).

\section{Nitrate reduction test}

Development of noncolor formation indicated (red) negative to result (Table 4).

\section{Glycine utilization}

After 48 hrs of incubation, ninhydrin solution was flooded on the agar surface color formation occurred with ninhydrin solution, hence the bacterium was negative to test for glycine utilization (Table 4).

\section{Growth on different media}

The growth of bacterium was checked in different media, such as nutrient media, Columbia agar, Brucella agar, Brain heart infusion agar, and Serum supplemented plate. Among the media higher level of growth was observed in Columbia and Brucella agar plate. The plates with nutrient agar were devoid of any bacterial growth (Table 4).

\section{Growth at different temperature}

The optimum temperature for growth was determined in H. pylori. In this study, different temperature regiments were followed such as 25 , $30,35,40$, and $45^{\circ} \mathrm{C}$. Among different temperatures, $25^{\circ} \mathrm{C}$ and $30^{\circ} \mathrm{C}$ had no growth but at 35 and $40^{\circ} \mathrm{C}$ good growth was observed whereas at $45^{\circ} \mathrm{C}$ no growth of $H$. pylori was observed (Table 4).

\section{Growth in salt tolerance}

Salt tolerance was determined in Brucella broth with sodium chloride added at different concentration $(0.5,0.75,1.0,1.25$ and $1.5 \%, \mathrm{w} / \mathrm{v})$. Good growth was observed up to $1.25 \% \mathrm{NaCl}$ whereas at $1.5 \% \mathrm{NaCl}$, growth was completely arrested (Table 4 ).

\section{Antibiotic resistance/sensitivity}

The antibiotics resistance and sensitivities are an essential assay for the pathogen. In the present research, different kinds of antibiotics such

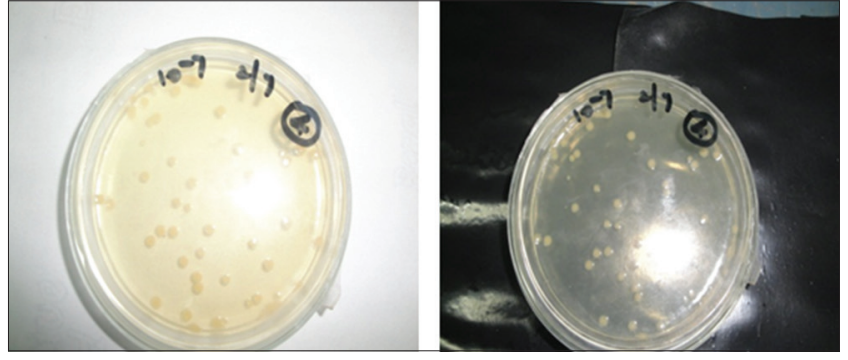

Fig. 1: Isolation of Helicobacter pylori from gastric patient in petri plate

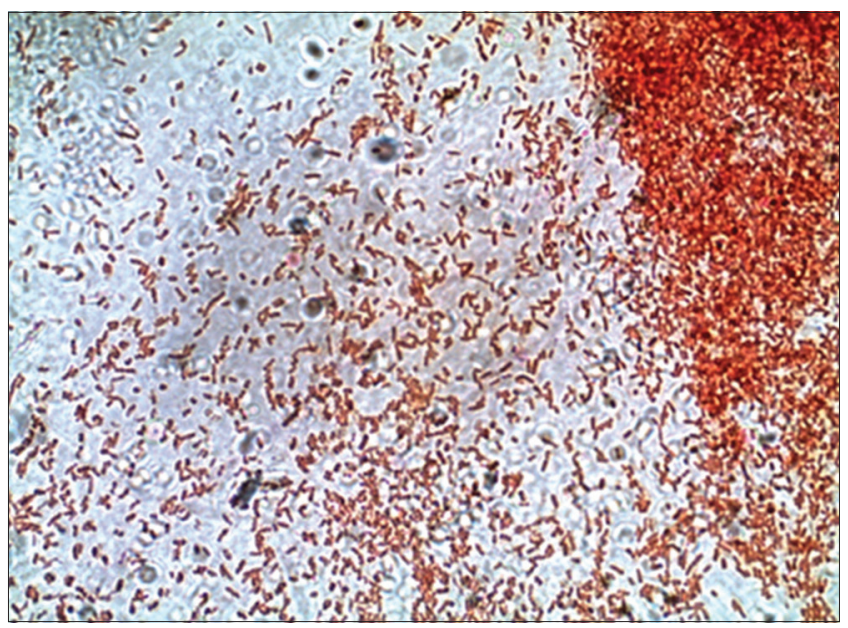

Fig. 2: Gram staining of Helicobacter pylori with microscopic observation

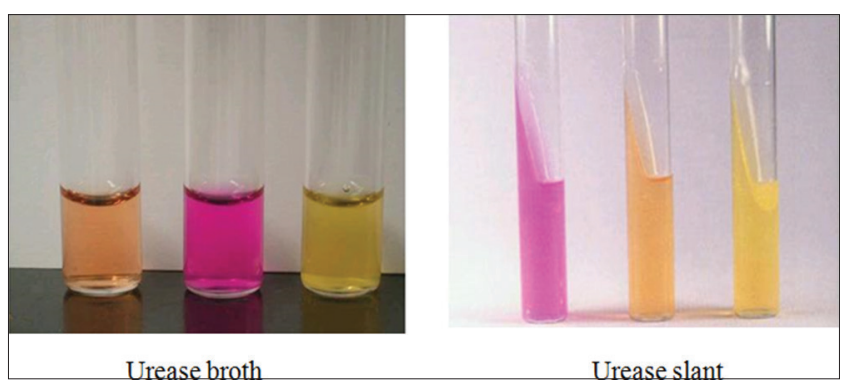

Fig. 3: Conformation of Helicobacter pylori through urease test

as nalidixic acid, trimethoprim vancomycin, penicillin, tetramycine, and cephalothin were used. Then, the MIC was recorded. Among the tested antibiotics, the bacterium showed moderate sensitivity to nalidixic acid, trimethoprim, and vancomycin. These resistant characters are also very much useful in selecting marker for classical genetic experiments (Table 4). 
Table 4: Biochemical characteristics by of $H$. pylori

\begin{tabular}{|c|c|}
\hline Assay & Observation \\
\hline Colony shape & $\begin{array}{l}\text { Round, small, translucent, } \\
2-3 \mathrm{~mm}\end{array}$ \\
\hline Cell shape & $\begin{array}{l}\text { Spiral, helical or curved with } \\
\text { blunt ends }\end{array}$ \\
\hline Cell motility & + \\
\hline Gram staining & - \\
\hline Urease & + \\
\hline Oxidase & + \\
\hline Catalase & + \\
\hline Nitrate reduction & - \\
\hline Glycine utilization & - \\
\hline \multicolumn{2}{|l|}{ Growth on } \\
\hline Nutrient agar & - \\
\hline Columbia agar & + \\
\hline Brucell agar & + \\
\hline Blood agar & + \\
\hline Brain heart infusion agar & + \\
\hline Serum supplement agar & + \\
\hline \multicolumn{2}{|l|}{ Growth at } \\
\hline $25^{\circ} \mathrm{C}$ & - \\
\hline $30^{\circ} \mathrm{C}$ & - \\
\hline $35^{\circ} \mathrm{C}$ & + \\
\hline $40^{\circ} \mathrm{C}$ & + \\
\hline $45^{\circ} \mathrm{C}$ & - \\
\hline \multicolumn{2}{|l|}{ Growth in $\mathrm{NaCl}(\%)$} \\
\hline 0.5 & + \\
\hline 0.75 & + \\
\hline 1.0 & + \\
\hline 1.25 & + \\
\hline 1.5 & - \\
\hline \multicolumn{2}{|c|}{ Resistance/sensitivity (50 $\mu \mathrm{g} / \mathrm{ml}$ ) } \\
\hline Nalidixic acid & + \\
\hline Trimethoprim & + \\
\hline Vancomycin & - \\
\hline Penicillin & - \\
\hline Tetramycine & - \\
\hline Cephalothin & - \\
\hline
\end{tabular}

H. pylori: Helicobacter pylori

\section{DISCUSSION}

H. pylori infection is one of the most common infections worldwide. However, it is not known, how H. pylori are transmitted and wherein the natural environment the organism resides [21]. It is likely that raw sheep's milk could be an intermediate transmission vehicle of $H$. pylori infection [22]. It has been reported that $H$. pylori are almost always acquired in childhood [23]. In other hand, Sasaki et al. [24] reported that H. pylori were detected in cow's feces and soil and the bacteria could invade the teat channel of a cow when it was sprawled on the ground including cow's feces and soil [25]. As reported by Fujimura et al. [26] that H. pylori gene is frequently detected in cow's milk samples, the samples might have been contaminated with the organism from contaminated soil. Furthermore, they have shown the possibility that $H$. pylori survive in raw milk. This study was investigated to isolate, identify, and found the total count of bacterial colony and occurence in gastric patients.

In this study, 43 males and 22 females were identified to have H. pylori infection out of 63 males and 33 females (totally 96 patients) and remaining were identified as non- $H$. pylori infectants. These results were comparable to Al-Sulami et al. [27] whose findings diagnosed 136 consecutive dyspeptic patients with peptic ulcer from mucosal antral biopsy specimens by endoscopy at Basra General Hospital, Iraq. Modified Columbia urea agar showed a higher isolation rate than classic Columbia agar $(67.6 \%$ vs. $44.1 \%$ of patients), and the results were obtained faster (24 hrs vs. 5-7 days) with more clear-cut identification. Among the total 136 patients with the positive peptic ulcer, 92 patients (67.6\%) showed positive evidence of $H$. pylori infection using bacterial

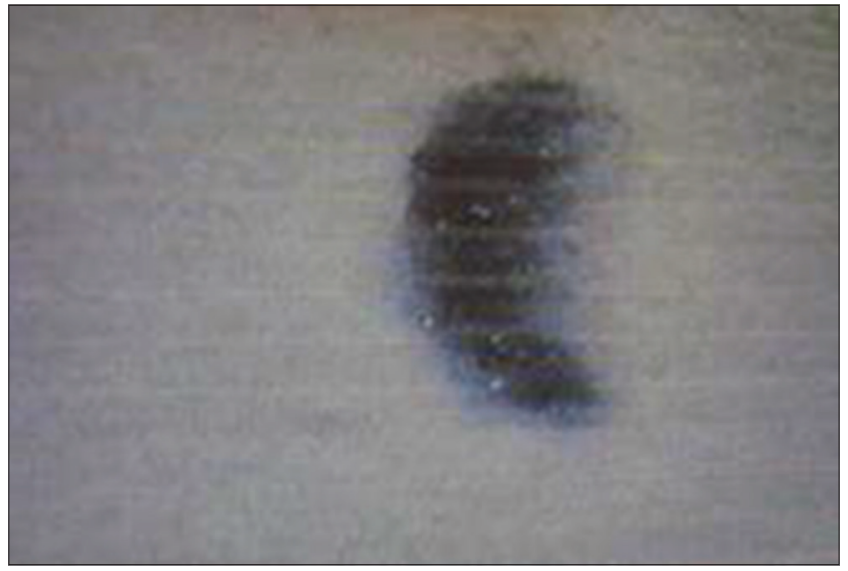

Fig. 4: Urease assay

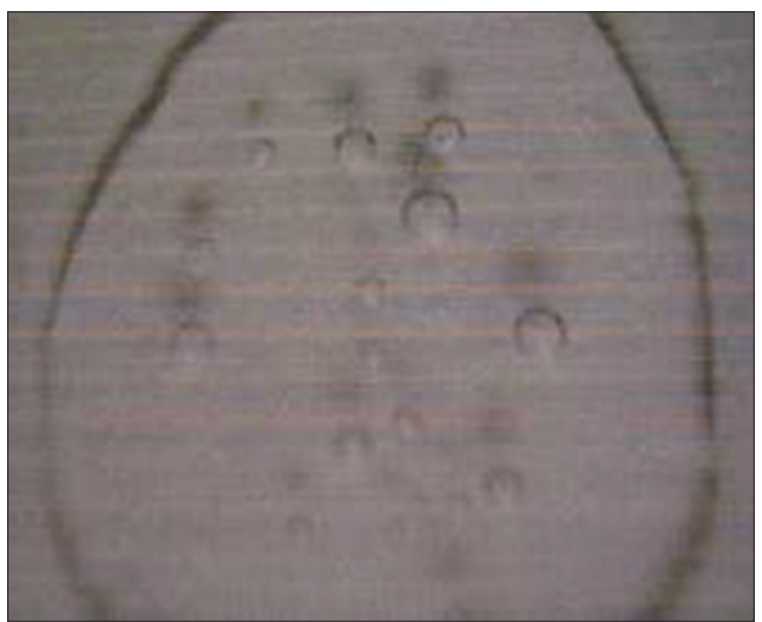

Fig. 5: Conformation of Helicobacter pylori through oxidase test

culture and 81 patients (59.6\%) by histopathological analysis. Among $H$. pylori ulcer patients, the highest detection rates of the bacterium (79.2\%) were recorded in the age group 41-50 years, while no single case was recorded in the age group $\leq 20$ years.

Several authors have been studied to evaluate the prevalence of $H$. pylori infection in peptic ulcer disease indicating a range from $60 \%$ to $70 \%$ at Iraq $[28,29]$. In this study, a bacterium $H$. pylori was isolated, purified, and identified by various biochemical tests such as catalase, urease and oxidase from the collected samples. Young et al. [30] have reported the culture of $H$. pylori was $1.75 \times 10^{-1} \mathrm{CFU} / \mathrm{ml}$ from gastric juice collected from the patient in Royal London Hospital, Whitechapel East London. Milyani and Barhameen [31] have characterized the cytopathic effect of $H$. pylori using albino rats and Swiss mice, isolated from the gastric biopsy of a patient at King Khalid National Guard Hospital, Jeddah City, Saudi Arabia.

As similar to our results toward Gram-staining, morphology and biochemical findings, Al-Sulami et al. [26] also reported the similar results toward Gram-staining, morphology and biochemical staining. All the isolated H. pylori were subjected to Gram-staining, identified the characteristics of this bacterium as Gram-negative and spiral shaped rods and positive result to biochemical tests (oxidase, catalase, and urease).

A variety of media, selective and nonselective, or a combination of both, have been proposed for use in the primary isolation of $H$. pylori, but the optimal method of recovery still remains to be established [32]. Columbia blood agar is a nonselective medium used for many years 
alone or in combination with other non-selective and selective media for culturing $H$. pylori from antral biopsy specimens taken from peptic ulcer patients during upper gastrointestinal endoscopy [33]. The isolation rate of $H$. pylori using this medium alone is very variable. Results as low as only $28.5 \%$ total isolation rate were reported by Piccolomini et al. [34]. The isolation rate of $H$. pylori using Columbia blood agar in the present study was 65\%; the colonies were few in number and tiny in size. Bacterial contamination of the medium was frequent. The contaminant bacteria were Pseudomonas spp., Proteus spp., and Klebsiella spp., the source of which could be contaminated biopsy forceps and contamination during obtaining, transporting and preparing of the defibrinated sheep blood added to the classic Columbia agar. The growth rate of $H$. pylori on this medium was slow, as 5-7 days were needed for the colonies to appear. Efforts have been invested to improve the reliability of Columbia agar and allows change it to become selective for H. pylori. In this study, we have used Columbia agar and obtained good results. According to the previous report, Columbia agar was found suitable for $H$. pylori culture.

The antibiotics resistance and sensitivities are an essential assay for the pathogen. In the present research, different kinds of antibiotics such as nalidixic acid, trimethoprim vancomycin, penicillin, tetramycine, and cephalothin were used. Then, the MIC was recorded. Among the tested antibiotics, the bacterium showed moderate sensitivity to nalidixic acid, trimethoprim, and vancomycin. These resistant characters are also very much useful in selecting marker for classical genetic experiments.

In our present study, the isolated bacterium $H$. pylori showed only a moderate sensitivity against various tested antibiotic (nalidixic acid, trimethoprim, and vancomycin). Similarly, Kumar et al. [35] also found the resistance of $H$. pylori against clarithromycin. Hence, they successfully developed clarithromycin loaded mucoadhesive microspheres to completely eradicate the H. pylori in the stomach.

Gastric cancer is the second most common cause of cancer-related mortality worldwide. Detection of the disease usually occurs at an advanced stage and overall survival rates for gastric cancer are poor. The present model for gastric cancer progression clearly maintains Helicobacter infection as the primary inducer of gastric metaplastic and neoplastic disease. H. pylori are a ubiquitous organism, infecting more than half the world's population. It has been suggested that this infection directly contributes to the formation of gastric cancer in up to $80 \%$ of cases; however, gastric malignancy develops in only a subset $(<1 \%)$ of infected patients. Predisposition to Helicobacter associated gastric cancer is most likely multifactorial, including the interaction of bacterial, host and environmental components. The development of intestinal-type gastric cancer is a multistep process [36]. It involves temporal progression from chronic gastritis to gastric atrophy, intestinal metaplasia, dysplasia, and finally gastric cancer. While a number of factors contribute to this transition, it has become clear that $H$. pylori are the primary trigger for neoplastic progression. The association between $H$. pylori and gastric cancer has been known for over a decade [21]. The early studies estimated the prevalence of $H$. pylori in patients with gastric cancer and recent work by Ekstrom et al. [37], Uemura et al. [38] using a combination of two or three methods to diagnose $H$. pylori infection have shown a much stronger association.

In this present investigation, in total, 96 patient's affected gastric ulcer, 19 patients have affected gastric cancer and 8 have non-gastric inflammation. The discovery of $H$. pylori by Warren and Marshall [6] changed the conventional concept of gastroduodenal ulcer disease. Studies, over the years, suggested a high correlation between $H$. pylori infection and peptic ulceration [39]. The prevalence of $H$. pylori infection shows a wide geographical variation [40]. Although it cannot be said that $H$. pylori cause ulceration, as half of the healthy population also harbors this organism, it had been shown that infection certainly makes the occurrence of ulcers more likely also, eliminating this bacterium reduces the rate of ulcer recurrence to $<25 \%$.
Childhood is the critical period for infection and transmission of disease. Most probably occurs from person to person. The iatrogenic route certainly exists but is considered relatively unimportant. Much debate surrounds the oral-oral and fecal-oral routes, which are probably more significant.

\section{CONCLUSION}

The human stomach is the only known reservoir of $H$. pylori. However, the possibility that there are other reservoirs cannot be excluded, as the conditions required for growth are met in the gastrointestinal tract of all warm-blooded animals. H. pylori have only been isolated from primates, but other Helicobacter species have been isolated from other animals. This suggests the presence of host specific binding sites, although the techniques required for isolation of Helicobacter species might differ between various hosts.

\section{ACKNOWLEDGMENT}

We thank Er. A.C.S. Arun Kumar, President, Dr. M.G.R Educational and Research Institute University for providing the necessary facilities. The first author thanks Science and Engineering Research Board (SERB), Government of India, for the award of SERB N-PDF (File No. PDF/2015/000375/LS) for financial support. We also thank Dean and Director, Faculty of Marine Sciences, Annamalai University.

\section{REFERENCES}

1. Ashwini P, Sumana MN, Shilpa U, Mamatha P, Dhananjaya BL, Farhan Z, et al. A review on Helicobacter pylori: Its biology, complications and management. Int J Pharm Pharm Sci 2014;7(1):14-20.

2. Farinha P, Gascoyne RD. Helicobacter pylori and MALT lymphoma. Gastroenterology 2005;128(6):1579-605.

3. Solnick JV, O'Rourk JL, Vandamme P, Lee A. The genus Helicobacter. In: Prokaryotes. $3^{\text {rd }}$ ed., Vol. 7. New York: Springer-Verlag; 2006.

4. Czinn S. Helicobacter pylori infection: Detection, investigation, and management. J Pediatr 2005;146(3):21-6.

5. Rothenbacker D, Brenner H. Burden of Helicobacter pylori and H. pylori-related diseases in developed countries: Recent developments and further implications. Microbes Infect 2003;5(8):693-703.

6. Warren JR, Marshall BJ. Unidentified curved bacilli in the stomach of patients with gastritis and peptic ulceration. Lancet 1983;1(8390):1311-5.

7. Goodwin CS. Helicobacter pylori gastritis, peptic ulcer, and gastric cancer: Clinical and molecular aspects. Clin Infect Dis 1997;25:1017-9.

8. Coghlan JG, Gilligan D, Humphries H, McKenna D, Dooley C, Sweeney E, et al. Campylobacter pylori and recurrence of duodenal ulcers a 12-months follow-up study. Lancet 1987;2:1109-11.

9. Rauws EA, Tytgat GN. Cure of duodenal ulcer associated with eradication of Helicobacter pylori. Lancet 1990;335(8705):1233-5.

10. Graham DY, Klein PD, Evans DJ. Campylobacter pylori detected noninvasively by the 13C-urea breath test. Lancet 1987;1(8543):1174-7.

11. Mobley HL, Mendz GL, Hazell SL, editors. Overview. In: Helicobacter pylori: Physiology and Genetics. Washington, DC: ASM Press; 2001. p. 3-5.

12. Marshall BJ. The Discovery that Helicobacter pylori, a spiral bacterium, caused peptic ulcer disease. In: Marshall BM, editor. Helicobacter Pioneers. Singapore: Blackwell Science Asia; 2002. p. 165-202.

13. Rossi G, Rossi M, Vitali CG, Fortuna D, Burroni D, Pancotto L, et al. A conventional beagle dog model for acute and chronic infection with Helicobacter pylori. Infect Immunol 1999;67:3112-20.

14. On SL. Identification methods for Campylobacters, Helicobacters and related organisms. Clin Microbiol Rev 1996;9(3):405-22.

15. Dunn BE, Cohen H, Blaser MJ. Helicobacter pylori. Clin Microbiol Rev 1997;10(4):720-41.

16. de Vos P, Garrity G, Jones D, Krieg NR, Ludwig W, Rainey FA, et al., editors. The firmicutes. Bergey's Manual of Systematic Bacteriology. $2^{\text {nd }}$ ed., Vol. 3. New York: Springer; 2006

17. Christensen WB. Urea Decomposition as a means of differentiating proteus and paracolon cultures from each other and from Salmonella and Shigella types. J Bacteriol 1946;52:461-6.

18. Smibert RM, Krieg NR. General characterization. In: Gerdhardt P, Murray RG, Costilow RN, editors. Manual of Methods for General Bacteriology. Washington, DC: American Society for Microbiology; 1981. p. 409-43. 
19. Kovacs N. Identification of Pseudomonas pyocyanea by the oxidase reaction. Nature 1956;178(4535):703.

20. Stanier RY, Palleroni NJ, Doudoroff M. The aerobic Pseudomonads: A taxonomic study. J Gen Microbiol 1966;43:159.

21. Parsonnet J, Shmuely H, Haggerty T. Fecal and oral shedding of Helicobacter pylori from healthy infected adults. J Am Med Assoc 1999;282(23):2260-2.

22. Dore AG, Lundin ER, Jensen LN, Birkeland O, Elliasen PE, Fichler C. Principle tectonic events in the evolution of the Northwest European Atlantic margin. In: Fleet AJ, Boldy SA, editors. Petroleum Geology of Northwest Europe: Proceedings of the $5^{\text {th }}$ Conference. London: Geological Society; 1999.

23. Rowland M. Transmission of Helicobacter pylori: Is it all child's play? Lancet 2000;355:332-3.

24. Sasaki K, Tajiri Y, Sata M, Fujii Y, Matsubara F, Zhao M, et al. Helicobacter pylori in the natural environment. Scand J Infect Dis 1999;31(3):275-9.

25. Plastridge WN. Bovine mastitis: A review. J Dairy Sci 1958;41:1141-81.

26. Fujimura S, Kawamura T, Kato S, Tateno H, Watanabe A. Detection of Helicobacter pylori in cow's milk. Lett Appl Microbiol 2002;35(6):504-7

27. Al-Sulami A, Al-Kiat HS, Bakker LK, Hunoon H. Primary isolation and detection of Helicobacter pylori from dyspeptic patients: A simple, rapid method. East Mediterr Health J 2008;14(2):268-76.

28. Al-Ajeel AM. Helicobacter pylori in common upper gastrointestinal disorders in Al-Anbar governorate. Al Anbar Univ J 1996;1:10-4.

29. Fatah HT, Al-Janabi AH. Prevalence of Helicobacter pylori in patients with peptic ulcer in Najaf. Al Kufa Univ J 1998;2:88-92.

30. Young KA, Akyon Y, Rampton DS, Barton SG, Allaker RP, Hardie JM, et al. Quantitativeculture of Helicobacter pylori from gastric juice: The potential for transmission. J Med Microbiol 2000;49:343-7.
31. Milyani RM, Barhameen AA. Survival of Helicobacter pylori in tap water and apple juice. J Med Res Inst 2003;24(3):158-68.

32. Karari EM. Endoscopic finding and the prevalence of Helicobacter pylori in chronic renal failure patients. East Afr Med J 2000;77(8):406-9.

33. Hartzen SH, Andersen LP, Bremmelgaard A, Colding H, Arpi M. Antimicrobial susceptibility of testing of 230 Helicobacter pylori strains: Importance of medium, inoculums and incubation time. Antimicrob Agents Chemother 1997;41:2634-9.

34. Piccolomini R, Di Bonaventura G, Festi D, Catamo G, Laterza F, Neri M. Optimal combination of media for primary isolation of Helicobacter pylori from gastric biopsy specimens. J Clin Microbiol 1997;35(6):1541-4.

35. Kumar AR, Venkateswaramurthy N, Vijayabaskaran M, Perumal P. Formulation of clarithromycin loaded mucoadhesive microspheres by emulsification - Internal gelation technique for anti - Helicobacter pylori therapy. Int J Pharm Pharm Sci 2010;3(2):173-7.

36. Correa P. Helicobacter pylori and gastric carcinogenesis. Am J Surg Pathol 1995; 19:37-43.

37. Ekstrom AD, Meltzer J, McNaughton BL, Barnes CA. NMDA receptor antagonism blocks experience-dependent expansion of hippocampal 'place fields'. Neuron 2001;31(4):631-8.

38. Uemura N, Okamoto S, Yamamoto S, Matsumura N, Yamaguchi S, Yamakido M, et al. Helicobacter pylori infection and the development of gastric cancer. N Engl J Med 2001;345(11):784-9.

39. Blecker U, McKeithan TW, Hart J, Kirschner BS. Resolution of Helicobacter pylori - Associated gastric lymphoproliferative disease in a child. Gastroenterology 1999;109(3):973-7.

40. Rodrigues MN, Queiroz DM, Bezerra Filho JG, Pontes LK, Rodrigues RT, Braga LL. Prevalence of Helicobacter pylori infection in children from an urban community in North-East Brazil and risk factors for infection. Eur J Gastroenterol Hepatol 2004;16(2):201-5. 